\title{
Immobilization of Cellulases Produced by Penicillium brevicompactum AUMC 10987, using Cross-Linkage, Chitosan-Coating and Encapsulation
}

\author{
Mohamed A. Abdel-Sater ${ }^{1}$, Nemmat A. Hussein ${ }^{1}$, Nashwa A. Fetyan ${ }^{2}$, Sabreen A. Gad ${ }^{3}$ \\ ${ }^{1}$ Botany and Microbiology Department, Faculty of Science, Assiut University, Assiut, Egypt \\ ${ }^{2}$ Microbiology Department, Soil, Water and Environment Research Institute, Agricultural Research Center, Giza, Egypt \\ ${ }^{3}$ Microbiology Department, Soil, Water and Environment Research Institute, Agricultural Research Center, \\ Shandaweel Research Station, Sohag, Egypt
}

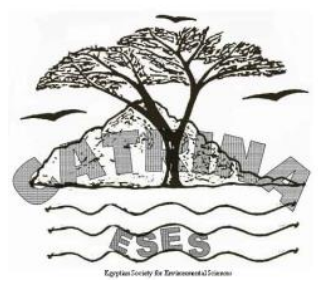

\begin{abstract}
This study was designed to optimize different conditions for improving enzyme production by Penicillium brevicompactum AUMC 10987, and to precipitate and immobilize cellulases by cross-linking method using glutaraldehyde, magnetic nanocarriers and encapsulation using $\mathrm{Ca}-$ alginate. Maximum activity of cellulase was achieved in medium containing date palm leaves, sodium nitrate, after 9 days incubation at $30^{\circ} \mathrm{C}$ and $\mathrm{pH}$ 6. Solid state fermentation was more convenient method in cellulase production. After ammonium sulphate precipitation, enzyme activities exceeded two-folded, constructing more stability for the enzyme structure and giving maximum activities at $50^{\circ} \mathrm{C}$ and $\mathrm{pH} 4.8$. Hence, precipitated enzyme could work in higher temperature and acidity conditions. The immobilization of cellulases by encapsulation was the most valuable technique retaining the activity of enzyme. Moreover, the immobilized enzyme remained active up to $80^{\circ} \mathrm{C}$, giving its maximum activity at $50^{\circ} \mathrm{C}$ and $\mathrm{pH} 5.5$. Enzyme encapsulated within alginate beads is preferred due to easy for formulation, mild gelation conditions, non-toxic, biocompatibility, low cost and resistance to microbial attack. Magnetic nannocariers immobilized enzyme had opportunity to be reused after 4 cycles/16 hours. The current study could provide a robust and highly valuable immobilized enzyme for different industrial and biotechnological applications.
\end{abstract}

Keywords: Ca-alginate, Cellulase, Encapsulation, Penicillium brevicompactum AUMC 10987

\section{INTRODUCTION}

Cellulose is a water insoluble long linear polymer composed of repeated units of $\beta$-D-glucose (8000-12000 glucose units) interlinked by $\beta-1,4$ glycosidic bonds (Somerville, 2006). Because of its highly ordered structure, cellulose is very hard to be degraded and that may explain its unusable and accumulation in nature as a waste material. The capacity to degrade the natural cellulose implies the synthesis of the entire cellulolytic system (Devi and Kumar, 2012). Cellulase enzyme complex consists of three major enzyme components: (a) endoglucanases (CMCase) (endo-1,4-D-glucanohydrolase, EC 3.2.1.4), hydrolyzing at random the internal glycosidic linkages of amorphous cellulose chain, (b) exoglucanases (FPase) (1,4- $\beta$-D-cellobiohydrolase, EC 3.2.1.91), acting in a progressive manner on the reducing or non-reducing ends of cellulose chains and (c) $\beta$-glucosidases (EC 3.2.1.21), these collectively hydrolyze polymer chain of cellulose producing glucose units as simple sugar molecules. Cellulase enzymes play a major role in industrial applications (Kirk et al., 2002). Also, microbial cellulase is used for bioremediation, waste water treatment and single cell protein (Alam, 2005). Cellulases have potential applications in pharmaceutical industry and biofuels production by fermentation of cellulosic biomass (Ali and Saad El-Dein, 2008). It was also proved that application of cellulolytic fungi improves the composting potential of cellulose waste, in addition (Hart et al., 2002).
The current demands of sustainable green methodologies have increased the use of enzymatic technology in industrial processes. But, the harsh conditions of industrial processes, increase propensity of enzyme destabilization, shortening their industrial lifespan, as well as, the free enzymes usually have poor stability towards $\mathrm{pH}$, heat or other factors and there is no possibility to recover and reuse (Kim et al., 2006). There are also limitations in using enzymes in largescale production such as high cost and lack of long-term operational stability. It is difficult to separate them from the reaction system, which limits the recovery of the enzyme and may lead to contamination of the final product (Vallet-Regi et al., 2001). Therefore, there is a great demand for finding ways to improve enzyme stability and reusability. All these requirements may be guaranteed by enzyme immobilization. Immobilization technique, as a very powerful tool, has been intensively conducted to prepare various high performance and economically-feasible biocatalysts with improved stability and reusability for biotechnological applications. The immobilized enzymes can work in a broader $\mathrm{pH}$ and temperature range showing higher thermal stability than the free enzymes (Xu et al., 2014).

The present work was designed to optimize the conditions to maximize cellulase production by Penicillium brevicompactum AUMC 10987; to immobilize cellulases using cross-linkage, chitosan coating and encapsulation to obtain robust enzyme with 
high quality for industrial and biotechnological applications was also investigated.

\section{MATERIALS AND METHODS}

\section{Optimization of cellulase production Fungal isolate tested}

Penicillium brevicompactum AUMC 10987 was isolated from rotted apple fruit, collected from Sohag city, Egypt. The isolate was identified based on macroscopic and microscopic features following the key and description of Pitt (1979). Inoculum was prepared from the fungus grown on Czapek's agar medium $(\mathrm{g} / \mathrm{l}$; glucose, 10; $\mathrm{NaNO}_{3}, \quad 3 ; \mathrm{KH}_{2} \mathrm{PO}_{4}, \quad 1 ; \mathrm{KCl}, \quad 0.5$, $\mathrm{MgSO}_{4} .7 \mathrm{H}_{2} \mathrm{O}, 0.5, \mathrm{FeSO}_{4}, 0.01$; and agar, 15) at $28^{\circ} \mathrm{C}$, for 7 days.

\section{Optimization parameters for maximum enzyme activity \\ Carbon sources}

Date palm leaves, wheat straw, corn cob, saw dust, filter paper and cellulose powder $(10 \mathrm{~g} / 25 \mathrm{ml}$ medium $)$ were separately inoculated with $4 \mathrm{ml}$ spore suspensions $\left(10^{7}\right.$ spores/ $\mathrm{ml}$ ) and incubated at $28^{\circ} \mathrm{C}$ for 7 days (AboState et al., 2010).

\section{Nitrogen sources}

Each of the nitrogen sources: Ammonium nitrate, peptone, beef extract and yeast extract was added to Czapek's medium with replacing glucose by date palm leaves (as the best carbon source) (Gautam et al., 2011). Fifty $\mathrm{ml}$ of the medium were dispensed into Erlenmeyer flask $(250 \mathrm{ml})$ and inoculated with $1 \mathrm{~cm}$ diam agar mycelial disc of 7 days- old fungal culture. The flasks were incubated at $28^{\circ} \mathrm{C}$ for 7 days.

\section{Temperature range}

The fungus was grown on medium containing date palm leaves and sodium nitrate (as the best nitrogen source), and incubated at different temperatures $(25,30$, $35,40,45$ and $50^{\circ} \mathrm{C}$ ) for 7 days.

\section{Incubation period}

The previous medium (containing date palm and sodium nitrate) was inoculated with $P$. brevicompactum AUMC 10987, incubated at the optimum temperature $\left(30^{\circ} \mathrm{C}\right)$ and enzyme activity was assessed after 3, 6, 9, 12 and 15 days of incubation.

\section{pH values}

To determine the best $\mathrm{pH}$ value for enzyme activity, Different pHs of 3, 5, 6, 7 and 12 were tested after 9 days of incubation.

\section{Enzyme assay}

Cellulase activity was assayed by mixing $0.9 \mathrm{ml}$ of $1 \%$ CMC (w/v) (pH 5.3) with $0.1 \mathrm{ml}$ of the clear supernatant, the mixture was incubated at $50^{\circ} \mathrm{C}$ for 30 min (Bailey et al., 1992). The reaction was stopped by adding $3 \mathrm{ml}$ of 3, 5-dinitrosalicylic acid (DNS) and boiled for $10 \mathrm{~min}$. After cooling, the developing colour was read at $540 \mathrm{~nm}$ using spectrophotometer model (UNICAM, Model Helios- Gamma). The liberated reducing sugar was quantified using glucose as a standard. One unit of cellulase is defined as the amount of enzyme that liberates $1 \mu$ mole of glucose equivalent per minute under the assay conditions (Ghose, 1987).

\section{Submerged fermentation}

Czapek's broth medium was used in which glucose was replaced by date palm leaves (the best carbon source). After sterilization, $250 \mathrm{ml}$ Erlenmeyer flask (containing $150 \mathrm{ml}$ medium) was inoculated with three agar discs of 7 days-old mycelial growth of $P$. brevicompactum, then, the flasks were incubated under shaking conditions $(120 \mathrm{rpm})$ at $30^{\circ} \mathrm{C}$ for 9 days. Cultures were filtered and centrifuged at $5000 \mathrm{rpm}$ for $10 \mathrm{~min}$. The clear supernatants were kept for crude enzyme precipitation.

\section{Solid state fermentation}

One hundred grams of small segments $\left(1 \mathrm{~cm}^{2}\right)$ of date palm leaves were mixed well with $70 \mathrm{ml}$ distilled water and put in Erlenmeyer flask (one liter each). After sterilization, the flask was inoculated with five agar mycelial discs of $P$. brevicompactum strain and incubated at $30^{\circ} \mathrm{C}$ under static conditions for 20 days. Then, cultures were filtered in the presence of $50 \mathrm{mM}$ sodium citrate buffer $(\mathrm{pH} \mathrm{5.3)}$ and centrifuged at 5000 rpm for $10 \mathrm{~min}$ and the clear supernatants were used for further studies (Abo-State et al., 2010).

\section{Enzyme precipitation}

\section{Using organic solvents}

Eight hundred $\mathrm{ml}$ of cold acetone or n-propanol were added separately drop wise to $200 \mathrm{ml}$ clear supernatant from submerged fermentation using separating funnel with slow stirring for 48 hours under cooling, then kept for 2 hours at $4^{\circ} \mathrm{C}$ for complete enzyme precipitation and centrifuged for 10 minutes at $5000 \mathrm{rpm}$ (Dalal et al., 2007). The supernatant was discarded and acetone or npropanol was evaporated at room tempruture and the precipitate was collected, weighed and dissolved in $5 \mathrm{ml}$ of $50 \mathrm{mM}$ sodium citrate buffer ( $\mathrm{pH} 4.8$ ). The enzyme activity and protein content were estimated in the solution. The remaining precipitate was kept for enzyme immobilization.

\section{Using ammonium sulphate}

Ammonium sulphate (70\%) was slowly added to 200 ml crude enzyme while gently stirring for 24 hours under cooling and kept overnight at $4{ }^{\circ} \mathrm{C}$ for complete precipitation, then centrifuged at $5000 \mathrm{rpm}$ for 15 minutes and the pellet was dissolved in citrate buffer for dialysis (Kalyani et al., 2015).

\section{Dialysis}

After precipitation, dialysis required to exclude high salted buffer crude enzyme, by placing the precipitate in dialysis bag and dialyzed against reverse osmotic water overnight at $4^{\circ} \mathrm{C}$ (Periyasamy et al., 2016). The precipitated enzyme inside the bag was lyophilized for removing more salts and water. 


\section{Determination of protein content}

Protein content of the precipitated enzyme was determined according to Lowry et al. (1951). The protein concentration was calculated using bovine serum albumin as standard.

\section{Determination of precipitated enzyme activity Filter paperase activity (FPase) assay}

It was assessed by adding $0.1 \mathrm{ml}$ precipitated enzyme solution (in $10 \%$ sodium citrate buffer) to $0.5 \mathrm{ml}$ of 0.05 M Na-citrate ( $\mathrm{pH} \mathrm{4.8);50} \mathrm{mg} \mathrm{filter} \mathrm{paper} \mathrm{(Whatman}$ No.1) strip $(1.0 \times 6.0 \mathrm{~cm})$ and $0.4 \mathrm{ml}$ distilled $\mathrm{H}_{2} \mathrm{O}$. The mixture was incubated at $50^{\circ} \mathrm{C}$ for $30 \mathrm{~min}$, then the reaction was stopped by adding $3 \mathrm{ml}$ DNS, boiled for 10 min and after cooling, the developing color was detected at $540 \mathrm{~nm}$ (Mandels et al., 1976). The liberated reducing sugar was quantified using glucose as a standard. One unit of FPase is defined as the amount of enzyme that liberates $1 \mu$ mole of glucose equivalent per minute under the assay conditions (Ghose, 1987).

\section{Carboxymethyl cellulase (CMCase)}

The enzyme was assayed by mixing $0.9 \mathrm{ml}$ of $1 \%$ carboxymethyl cellulose solution (CMC) prepared in 50 $\mathrm{mM}$ Na-citrate buffer ( $\mathrm{pH} 5.3)(\mathrm{w} / \mathrm{v})$ with $0.1 \mathrm{ml}$ precipitated enzyme solution, the mixture was incubated at $50^{\circ} \mathrm{C}$ for $30 \mathrm{~min}$ (Bailey et al., 1992). The enzyme activity was assessed as mentioned above.

\section{B-glucosidase assay}

To evaluate $\beta$-glucosidase, $0.9 \mathrm{ml}$ of cellobiose mixed with $0.1 \mathrm{ml}$ precipitated enzyme solution and the mixture was incubated at $50^{\circ} \mathrm{C}$ for $30 \mathrm{~min}$ and the enzyme activity was determined as the above (Ghose, 1987; Bailey et al., 1992).

\section{Effect of $\mathrm{pH}$ and temperature on the activity of precipitated enzyme}

The cellulase enzymes precipitated by ammonium sulphate were the most active one. Therefore, the effect of different temperatures $\left(30,40,50,60,70\right.$ and $\left.80^{\circ} \mathrm{C}\right)$ and $\mathrm{pH}$ values $(3.5,4,4.5,4.8,5,5.3,5.5,6,6.5$ and 7$)$ was studied to determine the optimum conditions for maximizing the enzyme activities. The activities of precipitated cellulases (FPase, CMCase and $\beta$ glucosidase) were assessed.

\section{Immobilization of crude enzyme \\ Cross-linking method using glutaraldehyde}

A mixture of $10 \mathrm{ml}$ enzyme solution and $10 \mathrm{ml}$ chitosan solution (2\% in acetic acid $2 \%)(\mathrm{pH} 5.0)$ was added drop wise into $10 \mathrm{ml}$ mixture of $\mathrm{NaHCO}_{3}(10 \%$ $\mathrm{w} / \mathrm{v}$ ) and glutaraldehyde (5\% w/v) (Yu et al., 2006). The reaction mixture was gently stirred at room temperature then the immobilized enzymes were filtered and washed several times with $50 \mathrm{mM}$ Na-citrate buffer solution. Enzymes activity and protein content were measured.

\section{Magnetic Nanocarriers}

Chitosan-magnetite nanocarriers were prepared by mixing $100 \mathrm{mg}$ of magnetite powder (Iron oxide, $\mathrm{Fe}_{3} \mathrm{O}_{4}$ )
$(15.2 \pm 2.6 \mathrm{~nm})$ in $20 \mathrm{ml}$ of $1 \%$ chitosan solution (prepared in 2\% acetic acid) (Krajewska, 2004). Then, $13.2 \mathrm{ml}$ of $0.5 \mathrm{M} \mathrm{KOH}$ was added gradually at $50^{\circ} \mathrm{C}$ under stirring. After 10 minutes, $0.5 \mathrm{ml}$ glutaraldehyde was added with continuous stirring for 30 minutes. Chitosan/magnetite particles were washed with $0.1 \mathrm{M}$ Na-acetate buffer ( $\mathrm{pH} 5.0$ ), then $10 \mathrm{ml}$ enzyme solution were added with stirring at $20^{\circ} \mathrm{C}$ for $30 \mathrm{~min}$, then left at $4^{\circ} \mathrm{C}$ overnight. The particles were washed, stored at $4{ }^{\circ} \mathrm{C}$ in $0.1 \mathrm{M} \mathrm{Na}$ - citrate buffer ( $\mathrm{pH}$ 5.0). The enzymes activity and protein content were determined.

\section{Encapsulation using Ca-alginate}

A methodology of the encapsulated enzymes adapted by Viet et al. (2013) was followed. Ten ml of enzyme solution were mixed with $40 \mathrm{ml} \mathrm{Na-alginate}(2 \%)$. The mixture was then extruded using a disposable syringe in $2 \% \mathrm{CaCl}_{2}$ solution at $3 \mathrm{~cm}$ distance above the gelling solution. After $30 \mathrm{~min}$, the beads were separated by filtration, washed three times with sterile distilled water then the enzymes activity and protein content were determined.

\section{Electron microscopy detection of immobilizeenzymes}

Enzymes immobilized by cross-linking and encapsulation were detected by scanning electron microscope JEOL, JSM-5400 LV (SEM) unit, Assiut University, Assiut, Egypt. While, immobilized enzyme on chitosan-coated magnetic nanoparticles $\left(\mathrm{Fe}_{3} \mathrm{O}_{4}-\mathrm{CS}\right)$ was detected by transmission electron microscope (TEM).

\section{Effect of temperature and pH on the immobilized enzyme Optimum temperature}

To determine the optimum temperature for enzyme activity immobilized by different methods, $0.05 \mathrm{~g}$ filter paper (for FPase), $0.9 \mathrm{ml}$ carboxymethyl cellulose (for CMCase) or cellobiose (for $\beta$-glucosidase) were separately incubated with $0.2 \mathrm{~g}$ immobilized enzyme in $1 \mathrm{ml}$ citrate buffer at different temperatures $(30,40,50,60$, 70 and $80^{\circ} \mathrm{C}$ ) for $30 \mathrm{~min}$ (Viet et al., 2013). The activity of the enzyme was assessed.

\section{Optimum pH}

The activities of the three enzymes (FPase, CMCase and $\beta$-glucosidase) were determined by adding the enzyme substrates into $50 \mathrm{mM} \mathrm{Na}$-citrate buffer and different $\mathrm{pH}$ values $(\mathrm{pH} 3.5,4,4.5,4.8,5,5.3$ 5.5, 6, $6.5,7)$ were adjusted then, the mixture was incubated with $0.2 \mathrm{~g}$ immobilized enzyme in $1 \mathrm{ml}$ citrate buffer at $50^{\circ} \mathrm{C}$ for $30 \mathrm{~min}$ (Yin et al., 2013).

\section{Reusability}

To evaluate the reusability of the immobilized enzymes resulted from different methods, $0.2 \mathrm{~g}$ of immobilized enzyme was added to enzyme substrate adjusted at the $\mathrm{pH}$ and incubated at optimum temperature. After the first reaction, the immobilized enzyme was washed with Na-citrate buffer and the activity was measured. The experiment was repeated 
and the activity in each time was measured (Rahim et al. 2013).

\section{Enzyme stability during storage}

Among the immobilized cellulases, encapsulated enzyme recorded the highest activity, so that, it was stored at $4{ }^{\circ} \mathrm{C}$ in Na-citrate buffer ( $\mathrm{pH} 5.3$ ) for 5 weeks. The enzyme activity was weekly evaluated (Yin et al. 2013).

Relative activity of immobilized cellulases (in relation to free enzyme) $=$

\section{activity of immobilized enzyme} activity of free enzyme

Relative activity of optimum immobilized cellulases = $\frac{\text { activity at different parameters ( } \mathrm{pH}, \text { temperature, }, . ., \mathrm{ect})}{\text { activity at optimum degree of the same parameter }} \mathrm{X} 100$

\section{RESULTS}

\section{Optimization of conditions for cellulolytic enzymes}

The results revealed that maximum enzyme production by $P$. brevicompactum was achieved in a medium with date palm leaves as a sole carbon source and sodium nitrate as a sole nitrogen source and initial $\mathrm{pH}$ 6, incubated at $30^{\circ} \mathrm{C}$ for 9 days (Figs. 1 and 2).
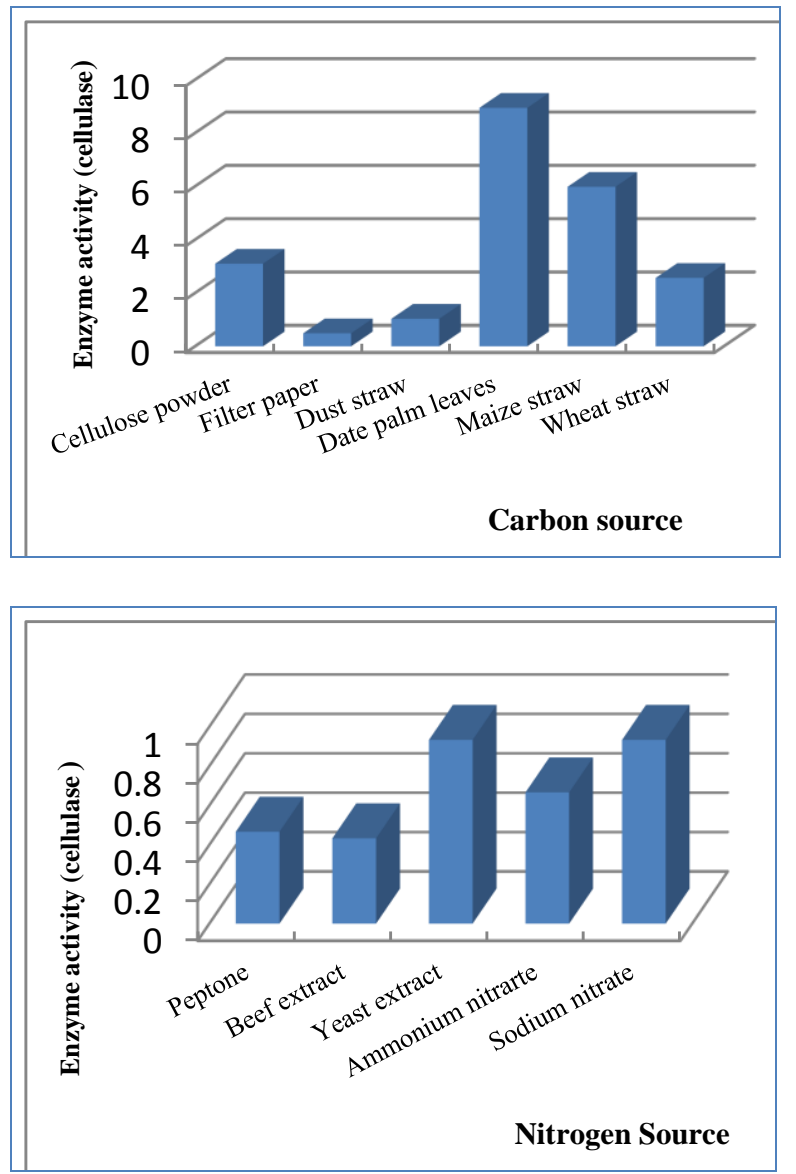

Figure (1): Effect of different carbon and nitrogen sources on cellulases production by $P$. brevicompactum AUMC 10987 in liquid medium.

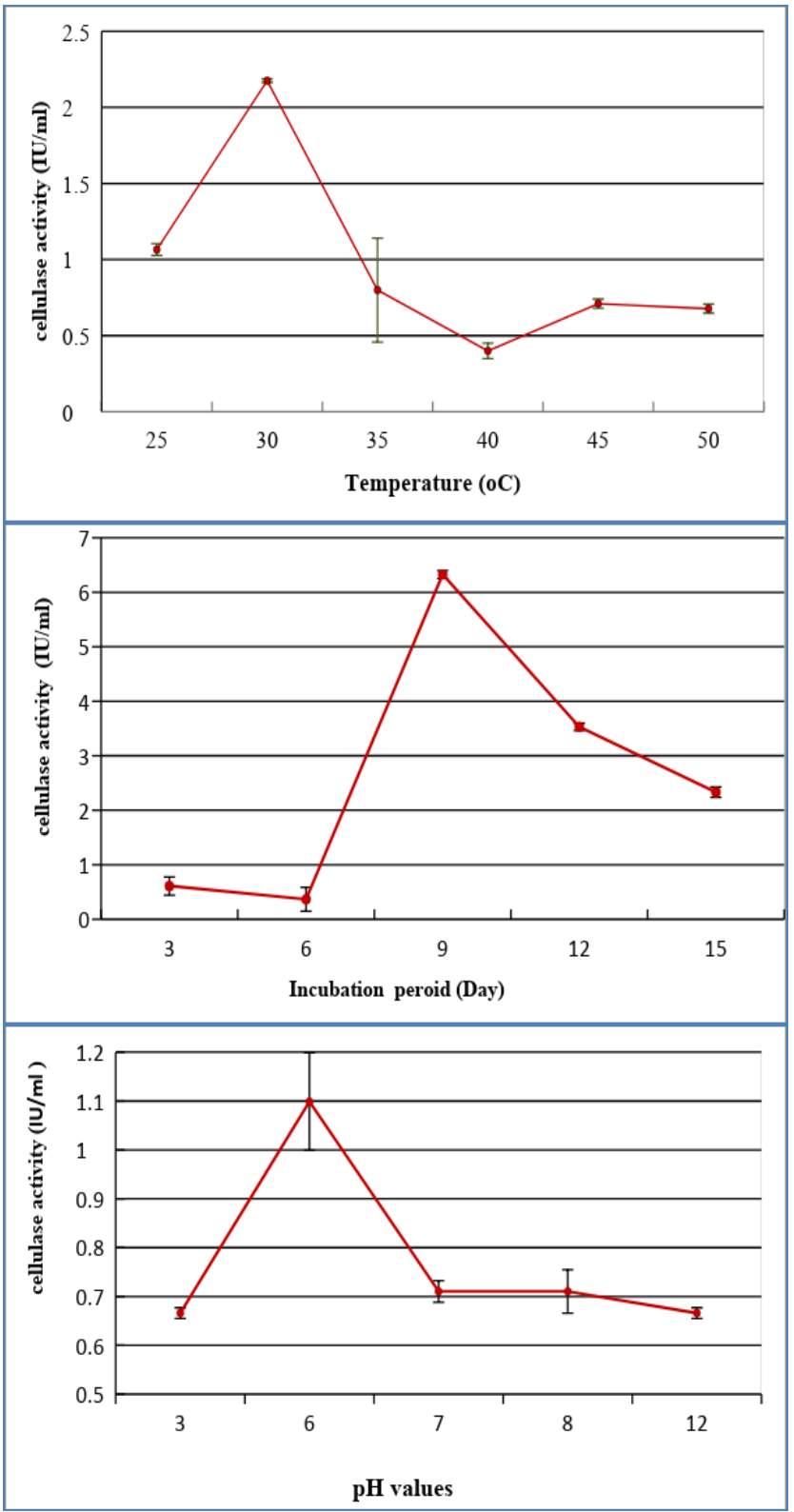

Figure (2): Effect of different incubation temperatures (a), incubation periods (b) and initial $\mathrm{pH}$ values (c) on cellulases produced by $P$. brevicompactum AUMC 10987 in liquid medium.

Enzyme production in submerged and solid state fermentations

The results showed that the activities of different enzymes (FPase, CMCase and $\beta$-Glucosidase) as well

as, protein content were respectively $3.5,7.2717 .66$ $\mathrm{IU} / \mathrm{ml} / \mathrm{min}, 154.7 \mu \mathrm{g} / \mathrm{ml}$ in solid state fermentation (SSF); while in submerged fermentation (SF) were 2.55, 5.86, $12.89 \mathrm{IU} / \mathrm{ml} / \mathrm{min}$ and $57.7 \mu \mathrm{g} / \mathrm{ml}$ (Fig. 3).

\section{Activities of precipitated cellulases}

Generally, partial purification of enzymes improved their activities, either by precipitation (FPase, 8.07; CMCase, 18.26 and $\beta$-Glucosidase, $48.25 \mathrm{IU} / \mathrm{ml} / \mathrm{min})$, npropanol precipitation $(5.66,14.66$ and $35.87 \mathrm{IU} / \mathrm{ml} / \mathrm{min}$ ) or acetone precipitation $(4.22,12.25$ and 27.32 $\mathrm{IU} / \mathrm{ml} / \mathrm{min}$ ) 
(Fig. 4). Moreover, protein content was increased after precipitation $(214.4,1997.7$ and $156.03 \mu \mathrm{g} / \mathrm{ml}$ by the three precipitation methods respectively.

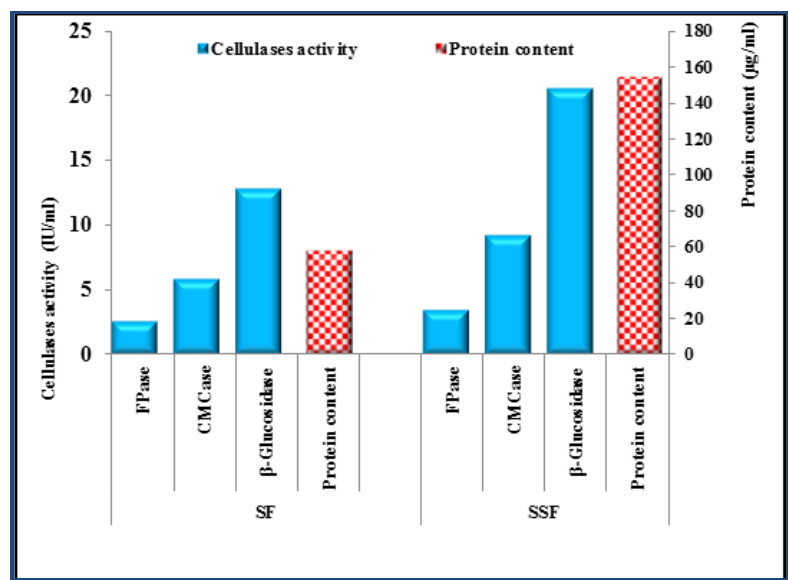

Figure (3): Cellulases activities and protein content produced by $P$. brevicompactum AUMC 10987 in submerged and solid state fermentations.

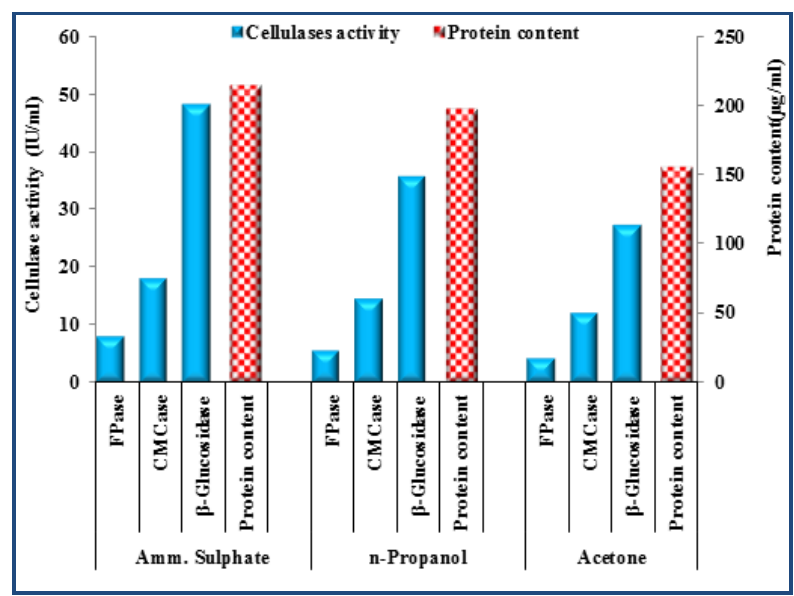

Figure (4): Cellulases activities and protein content measured after precipitation of enzyme by ammonium sulphate, n-prpanol and acetone.

\section{Effect of temperature and $\mathrm{pH}$ on partially purified} enzyme

Among different temperatures $\left(30-80^{\circ} \mathrm{C}\right)$ and $\mathrm{pH}(3.5-$ 7) tested, the precipitated enzyme exhibited their maximum activity at $50^{\circ} \mathrm{C}$ and $\mathrm{pH} 4.8$ (Supplementary S1)

\section{Immobilization of cellulases by different methods and their effects on enzyme activities}

Cross-linking using glutaraldehyde

It was observed that, under scanning electron microscope (SEM), glutaraldehyde links with amino groups in enzyme molecules forming cross-linked immobilized cellulases with matrix shape (Fig. 5a). It is worthy to mention that, cross-linking retained about $71.4,73$ and $75.61 \%$ relative enzyme activities for FPase, CMCase and $\beta$-glucosidase respectively.

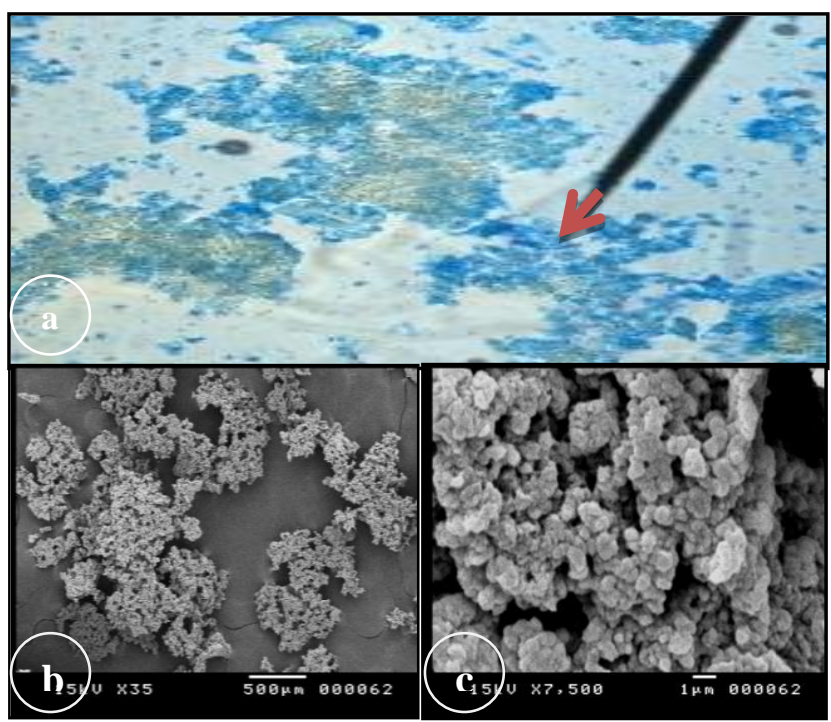

Figure (5a) Morphology of cross-linking immobilized cellulases under light microscope (a) and under scanning electron microscope $(\mathrm{b}, \mathrm{c})$.

\section{Magnetic nannocarriers}

The immobilization of cellulases on magnetic nannocariers required coated material such as chitosan which is added during immobilization procedures, using chitosan enzyme molecules that aggregate around nanoparticles formed chitosan-enzyme coated magnetic nanoparticles (CH-MNPs) (Fig. 5b). In comparison with the free enzymes, higher relative activities $(79.1 \%, 80.61 \%$ and $83.48 \%)$ were obtained for FPase, CMCase and $\beta$-glucosidase respectively.

\section{Encapsulation using Ca-alginate}

The beads resulted from encapsulation of the enzyme by $\mathrm{Ca}$-alginate were characterized by irregular shapes, 900-1000 $\mu \mathrm{m}$ size (Fig. 5c). The encapsulated FPase, $\mathrm{CMCase}$ and $\beta$-glucosidase had high relative activities of $81.78,82.75$ and $84.62 \%$ respectively

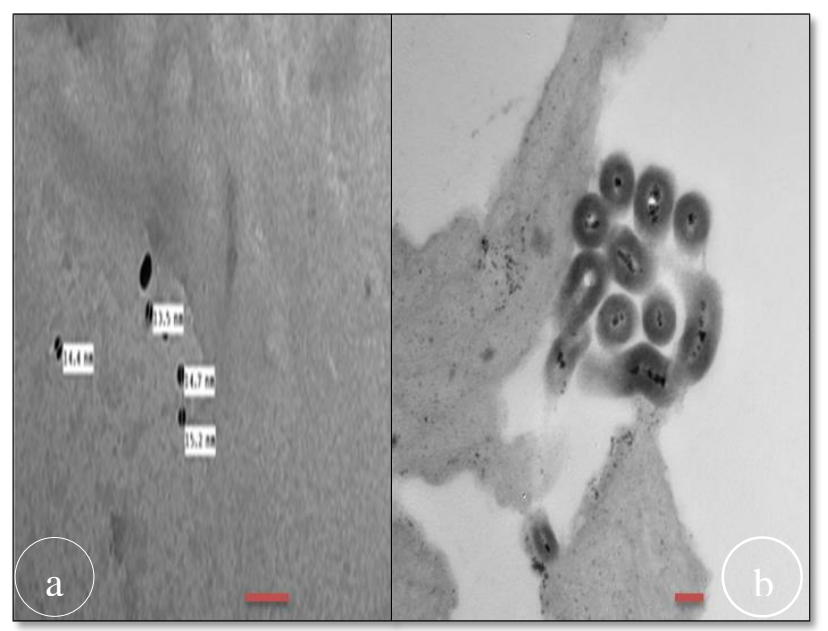

Figure (5b) Transmission electron microscopy (TEM) images of (a) Iron oxide nanoparticles $(\mathrm{IONPs})\left(\mathrm{Fe}_{3} \mathrm{O}_{4}+\mathrm{Fe}_{2} \mathrm{O}_{3}\right.$, diameter in mean $=$ $15.2 \pm 2.6 \mathrm{~nm}$ ), and (b) CH-MNPs immobilized cellulase. Where the scale bar $=100 \mathrm{~nm}$. 


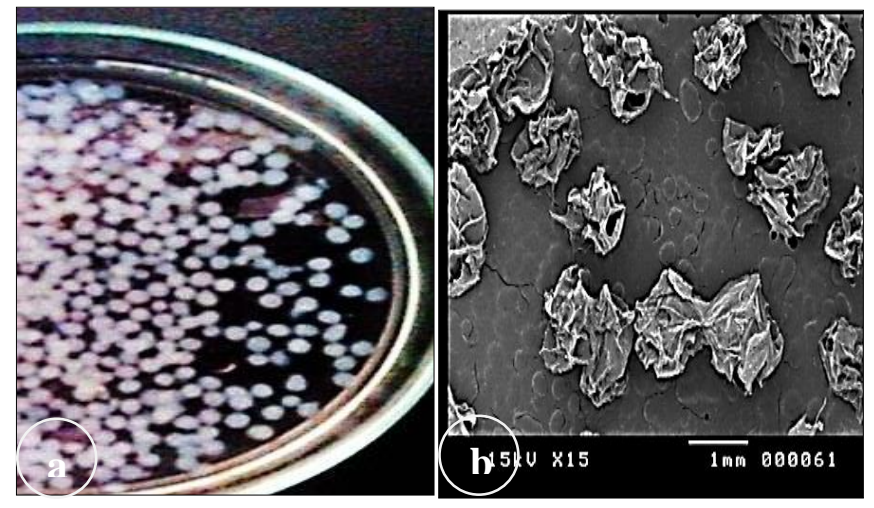

Figure (5c) Beads of immobilized cellulases encapsulated by Caalginate in petri dish (a) and under scanning electron microscope (b, c).

Optimization of some parameters for immobilized enzymes

\section{Temperature}

The maximum activity of FPase and CMCase immobilized by cross-linking reached 5.76 and 13.33 $\mathrm{IU} / \mathrm{ml} / \mathrm{min}$ respectively at $50^{\circ} \mathrm{C}$ (Supplementary S2a). However, the optimum temperature for $\beta$-glucosidase, which gave $36.48 \mathrm{IU} / \mathrm{ml} / \mathrm{min}$, was $60^{\circ} \mathrm{C}$. Also, enzyme immobilized by magnetic nannocarriers gave the best activity at $60^{\circ} \mathrm{C}$ (Supplementary S2b). Immobilization on Ca-alginate maintained maximum enzyme activities at $50^{\circ} \mathrm{C}(6.65,15.11$ and $40.83 \mathrm{IU} / \mathrm{ml} / \mathrm{min}$ for FPase, CMCase and $\beta$-glucosidase respectively) and these immobilized enzymes showed thermostability up to $80^{\circ} \mathrm{C}$ ((Supplementary S2c).

\section{Optimum pH}

The results showed that, from different $\mathrm{pH}$ values tested (4-7), $\mathrm{pH} 6$ yielded the highest cross- linking immobilized enzyme activities (3.91, 15.74 and 40.04 $\mathrm{IU} / \mathrm{ml} / \mathrm{min}$ ) for FPase, CMCase and $\beta$-glucosidase respectively (Supplementary S3a). The maximum enzyme activities for FPase, CMCase and $\beta$-Glucosidase (4.33, 17.86 and 38.04 respectively) immobilized by magnetic nannocarriers were obtained at $\mathrm{pH} 6$ (Supplementary S3b).

Using Ca-alginate for cellulase encapsulation, the maximum activities $(4.43,18.56$ and $45.07 \mathrm{IU} / \mathrm{ml} / \mathrm{min}$ forFPase, CMCase and $\beta$-glucosidase respectively) were shown at pH 5.5 (Supplementary S3a).

\section{Enzyme reusability}

Results in Figure (6a) revealed that, the cross-linking immobilized enzyme could be reused twice after the main reaction, whereas after 8 hours, the immobilized enzyme activities decreased to $51.55,64.58$ and $75.38 \%$ for FPase, CMCase and $\beta$-glucosidase respectively, while after that, the immobilized enzyme lost its activity. It was found that immobilization by magnetic nannocarriers was the ideal technique to maintain stability and reusability of the immobilized enzyme forup to five consecutive cycles at $60^{\circ} \mathrm{C}$, whereas, the immobilized $\beta$-glucosidase maintained about $67 \%$ while, FPase and CMCase maintained about $62.5 \%$ and 41.59 $\%$ of their activities respectively, after the third cycle
(Fig. 6b). The $\beta$-glucosidase in Ca-alginate entrapped enzyme showed $13.33 \%$ relative activity after four cycles (Fig. 6c).

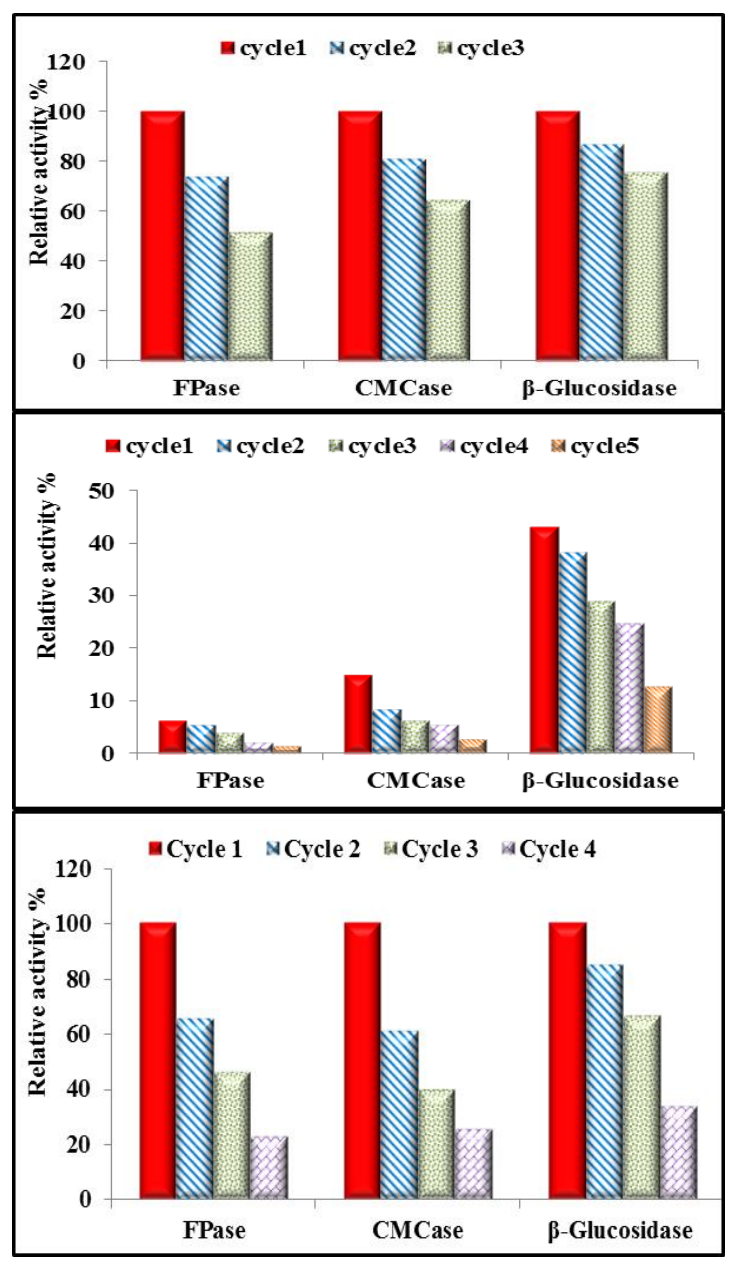

Figure (6): Reusability of (a) cross-linking, (b) magnetic nannocarriers, and (c) Ca-alginate encapsulated immobilized enzymes.

The influence of storage periods on the activity of CMCase immobilized in Ca-alginate

From the standpoint of preference of $\mathrm{Ca}$-alginate as immobilizing agent, beads of enzyme immobilized in Ca-alginate were stored in Na-citrate buffer ( $\mathrm{pH} \mathrm{5.3)} \mathrm{at}$ $4^{\circ} \mathrm{C}$ for 5 weeks and the activity was measured every week. The obtained results revealed that the relative activity was reduced during storage from $100 \%$ to 18.66 $\%$ at the end of storage period (after 5 weeks) (Table 1).

Table (1): Relative activity of CMCase enzyme immobilized by encapsulation at different storage periods

\begin{tabular}{c|c}
\hline $\begin{array}{l}\text { Storage Periods / } \\
\text { weeks }\end{array}$ & $\begin{array}{c}\text { \% Relative } \\
\text { activity }\end{array}$ \\
\hline 0 & 100 \\
1 & 80.74 \\
2 & 56.25 \\
3 & 42.36 \\
4 & 20.65 \\
5 & 18.66 \\
\hline
\end{tabular}




\section{DISCUSSION}

The maximum amount of endo- $\beta-1,4$-glucanase enzyme was produced in the presence of sodium or calcium nitrate as nitrogen sources, after 8 days of incubation at $30^{\circ} \mathrm{C}$ with $\mathrm{pH} 6$ of Alternaria alternata, A. citri, Cochliobolus spicifer and C. globosum (El-said et al. 2014). Also, sodium nitrate was found to be the best nitrogen source for cellulase production by Aspergillus fumigatus (Sherief et al. 2010). Some other studies showed also that $30^{\circ} \mathrm{C}$ and $\mathrm{pH} 6$ were the optimum conditions for cellulase production by some fungal species such as Trichoderma atroviride (Bairagi 2016) and Penicillium sp. (Prasanna et al. 2016). In India, Padmavathi et al. (2012) and Isaac and Abu-Tahon (2015) found that, maize straw and corn stover were the best carbon sources used for FPase, CMCase and $\beta$ glucosidase production by $A$. terreus and Mucor plumbeus among the other lignocellulosic tested materials.

However, in both fermentation methods, $\beta$-glucosidase showed the highest activity among the three enzymes tested. This may be attributed to the less complexity and hence easy assimilation of the substrate by the fungal isolate. In this respect, SSF for the production of cellulases offers numerous advantages such as high productivity, relatively high concentrations of the products and less effluent generation (Acharya and Chaudhary 2012) as well as, higher yields and product stability (Singhania et al. 2009).

It seems that different precipitants constructed a more stable structure for the enzyme and keep the enzyme in its origin conformational even after immobilization (Sulaiman et al. 2014). In consistence with our results, Kalyani et al. (2015) reported that the activity of partially purified enzyme by ammonium sulphate increased than that of the crude enzyme. Therefore, ammonium sulphate has been the most widely precipitant used in protein separation and purification among many other salts because of its high solubility and is relatively inexpensive (Duong-Ly and Gabelli 2014).

Our results were in harmony with the findings of $\mathrm{Xu}$ et al. (2015) and Zhang et al. (2016). pH 5 was also reported as optimum $\mathrm{pH}$ for maximum enzyme activities of A. niger and A. fumigates (Immanuel et al. 2007), while, $\mathrm{pH} 4.5$ gave the maximum activity of free cellulose in the study of $\mathrm{Xu}$ et al. (2015).

The slight decline in activity of cross-linked immobilized cellulase was also reported by Sheldon (2007). This may be due to the reaction of cross-linker with amino acid residues that are crucial for the activity of the enzymes or when the concentration of glutaraldehyde solution was too much, lead the enzyme molecules to form multi-point binding with the carrier and increase the amount of the enzyme bound to active aldehyde may change the spatial structure of the active center of enzyme (Chen et al. 2013). Cross-linking technique utilizes a bi- or multifunctional compound to bind with the functional groups of the enzyme to form insoluble cross-linked complex, whereas, the enzyme molecules are covalently bounded to each other to create a matrix. Successful preparation of cross-linked enzyme aggregates (CLEAs) from a broad range of enzymes was obtained (Šulek et al. 2011).

The immobilization using iron oxide nanoparticles, enhanced the biocatalytic properties of an enzyme, including stability and reusability can provide higher surface area for high loading of enzyme (García et al. 2014), this may explain the relatively higher enzyme activities than that obtained by cross-linking. Recently, ferric oxide $\left(\mathrm{Fe}_{3} \mathrm{O}_{4}\right)$ magnetic nanoparticle have been paid much attention by several researchers for immobilization of cellulases, due to its non or at least low toxicity, good biocompatibility, very good candidate, without residual magnetism, with simple, quick and lowcost collection of enzymes from a complex mixture with an external magnetic field, high enzyme loading capability, due to their large specific surface area and lower diffusion limitation in solution ( $\mathrm{Li}$ et al. 2013; Tang et al. 2014).

Cellulases encapsulated by $\mathrm{Ca}$-alginate retained up to $84.62 \%$ of their activities, similar results were obtained by Viet et al. (2013). Enzyme encapsulated within alginate beads is preferred due to easy for formulation, mild gelation conditions, non-toxic, biocompatibility, low cost and resistance to microbial attack (Won et al., 2005; Quiroga et al. 2011). Encapsulation is the process by which the enzyme is enclosed physically or chemically within semi-permeable membrane. Attaching or entrapping the protein in support materials can prevent the enzyme from leaving while allowing substrates, products, and co-factors to permeate to the enzyme (Martinek and Mozhaev 1985). Calcium alginate is used extensively because it provides stability and biochemically inert (Abd El-Ghaffar and Hashem 2013; Viet et al. 2013).

Based on our results, it was found that cross-linked cellulase immobilized by chitosan and glutaraldehyde had optimum temperature at $50^{\circ} \mathrm{C}$ (Podrepšek et al. 2012; Yu et al. 2012; Li et al. 2015). Also, during studying on immobilized cellulases activities retained $70 \%$ of the maximum activity at $50^{\circ} \mathrm{C}$ in the study of Dal Magro et al. (2016). However, in the current study, the optimum temperature for $\beta$-glucosidase, which gave $36.48 \mathrm{IU} / \mathrm{ml} / \mathrm{min}$, was $60^{\circ} \mathrm{C}$. Also, enzyme immobilized by magnetic nannocarriers gave the best activity at $60^{\circ} \mathrm{C}$. This was in accordance to the findings of Abraham et al. (2014) on immobilization using cellulase complex binding onto magnetic nanoparticle. It was reported that the immobilization of the enzyme on the solid support increased the thermostability of the enzyme which can tolerate higher temperature whereas the free enzyme that denature at high temperature (Kumar et al. 2018)

In respect to our results, Chang and Juang (2005) reported the same optimum temperature of encapsulated cellulases. It was suggested that, decreasing the enzyme activities above $50^{\circ} \mathrm{C}$ may be related to the vibration and movement of the enzyme molecule which can affect the hydrogen bonding in the enzymes structure. Therefore, this may reduce the catalytic power of enzymes and 
lastly tend to denaturate the enzymes (Mat Radzi et al. 2005; Lee et al. 2008; Abd Rahim et al. 2013).

Laing et al. (2006) found that the optimal pH of crosslinked urease was 6.5. The maximum enzyme activities for FPase, CMCase and $\beta$-Glucosidase (4.33, 17.86 and 38.04 respectively) immobilized by magnetic nannocarriers were obtained at $\mathrm{pH}$ 6. Similar findings were also obtained by Choi et al. (2009) and Zahoor et al. (2011).

Almost our results are similar to the finding of Keerti et al. (2014) for the immobilized $\beta$-glucosidase in alginate gel which had the highest activity at $\mathrm{pH} 5.0$. It was deduced that, the surfaces of the beads which localize the enzymes have a cationic and anionic nature that will produce microenvironment charges and then it will affect the nature of active enzyme. So, the increasing or decreasing of $\mathrm{pH}$ from the optimum value could reduce the activity of enzymes due to charge acquired by the support (Abd Rahim et al. 2013).

One of the main targets for immobilization is the reuse of the enzyme to reduce cost for industrial process. In this respect, Khorshidi et al. (2016) reported that the CMCase activity decreased sharply to $30 \%$ of initial activity after two cycles of hydrolysis, however retained this level up to 6 cycles. Reuse of immobilized enzyme for more than one cycle may be attributed to multipoint, multi-subunit immobilization or generation of favorable environments ( $\mathrm{Xu}$ et al. 2014), but decreasing the activity could be related to the denaturation and the leakage of enzyme upon use and diffusional effects (Ye et al. 2006). It is worthy to mention that, our results were relatively higher than that obtained by Abraham et al. (2014) who found that the immobilized enzyme retained $50 \%$ of its activity after four cycles. In accordance, Keerti et al. (2014) mentioned that the immobilized $\beta$ glucosidase in alginate was reused 4 times, with gradual decrease in the residual activity to $17.85 \%$.

Our results were relatively more valuable than the finding of Keerti et al. (2014) who, reported that the immobilized cellulases in alginate retained about $17.74 \%$ of its original activity at $4^{\circ} \mathrm{C}$ after 25 days. However, Yin et al. (2013) found that the immobilized cellulase showed a gradual decrease in activity and lost $14 \%$ of initial activity after 4 weeks.

\section{Conclusion}

Immobilized enzyme has superiority over free enzyme in different biotechnological processes, due to its high stability and low cost. The current study could provide a robust and highly valuable immobilized enzyme for different industrial and biotechnological applications.

This research did not receive any specific grant from funding agencies in the public, commercial, or not-forprofit sectors.

\section{REFERENCES}

ABD EL-GHAFFAR, M.A., M.S. HASHEM. 2013. Calcium Alginate Beads Encapsulated PMMA-g-CS Nano-Particles for $\alpha$-chymotrypsin Immobilization. Carbohydrate Polymers 92: 2095-2102.
ABD RAHIM, S.N., K.U.A. SULAIMAN, K.H. HAMID. 2013. Performance of Encapsulated Enzymes within Calcium Alginate-clay Beads in a Stirred Bioreactor for Biosugar Production. Advances in Environmental Biology Special Issue for International Conference of Advanced Materials Engineering and Technology (ICAMET 2013), November 2013, Bandung Indonesia, 28-29.

ABO-STATE, M.A.M., A.I. HAMMAD, M. SWELIM, R.B. GANNAM. 2010. Enhanced Production of Cellulase(S) by Aspergillus spp. Isolated from Agriculture Wastes by Solid State Fermentation. American-Eurasian Journal of Agriculture and Environmental Science 8(4): 402-410.

ABRAHAM, R.E., M.L. VERMA, C.J. BARROW, M. PURI. 2014. Suitability of Magnetic Nanoparticle Immobilized Cellulases in Enhancing Enzymatic Saccharification of Pretreated Hemp Biomass. Biotechnology Biofuels 7: 1-12.

ACHARYA, S., A. CHAUDHARY. 2012. BioProspecting Thermophiles for Cellulase Production: a review.Brazilian Journal of Microbiology 43: 844856.

ALAM, M.Z., N. MUHAMMAD, M.E. MAHMAT. 2005. Production of Cellulase from Oil Palm Biomass as Substrate by Solid State Bioconversion. American Journal of Applied Science 2(2): 569-572.

ALI, U.F., H.S. SAAD EL-DEIN. 2008. Production and Partial Purification of cellulase complex by Aspergillus niger and A. nidulans Grown on Water Hyacinth Blend. Journal of Applied Sciences Research 4(7): 875-891.

BAILEY, M.J., P. BIELY, K. POUTANEN. 1992. Interlaboratory Testing of Methods for Assay of Xylanase Activity. Journal of Biotechnology 23: 257270.

BAIRAGI S. 2016. Optimization of Cellulase Enzyme from Vegetable Waste by using Trichoderma atroviride in Solid State Fermentation. Journal of Environmental Science Toxicology and Food Technology 10: 68-73.

CHANG, M.Y., R.S. JUANG. 2005. Activities, Stabilities, and Reaction Kinetics of Three Free and Chitosan-Clay Composite Immobilized Enzymes. Enzyme and Microbial Technology 36: 75-82.

CHEN, H., Q. ZHANG, Y. DANG, G. SHU. 2013. The Effect of Glutaraldehyde Cross-Linking on The Enzyme Activity of Immobilized $\beta$-galactosidase on Chitosan Bead. Advance Journal of Food Science and Technology 5: 932-935.

CHOI, I.S., S.G. WI, S.R. JUNG, D.H. PATEL, H.J. BAE. 2009. Characterization and Application of Recombinant $\beta$-glucosidase $(\mathrm{BglH})$ from Bacillus licheniformis KCTC 1918. Journal of Wood Science 55: 329-334.

DAL MAGRO, L., P.F. HERTZ, R. FERNANDEZLAFUENTE, M.P. KLEIN, R.C. RODRIGUES. 2016. Preparation and Characterization of CombiCLEAs from Pectinases and Cellulases: a potential Biocatalyst for Grape Juice Clarification.RSC Advances 6: 27242-27251. 
DALAL, S., A. SHARMA, M.N. GUPTA. 2007. A Multipurpose Immobilized Biocatalyst with Pectinase, Xylanase and Cellulase Activities. Chemistry Central Journal 1: 1-5.

DEVI, M.C., M.S. KUMAR. 2012. Production, Optimization and Partial Purification of cellulase by Aspergillus niger Fermented with Paper and Timber Sawmill Industrial Wastes. Journal of Microbiology Biotechnology Research 2(1): 120-128.

DUONG-LY, K.C., S.B. GABELLI. 2014. Salting out of Proteins using Ammonium Sulfate Precipitation. Methods in Enzymology 541: 85-94.

EL-SAID, A.H.M., A. SALEEM, T.A. MAGHRABY, M.A. HUSSEIN. 2014. Cellulase Activity of some Phytopathogenic Fungi Isolated from Diseased Leaves of Broad Bean. Archives of Phytopathology and Plant Protection 47: 2078-2094.

GARCÍA, P.F., M. FREIHERR VON ROMA, S. REINLEIN, M. WOLF, S. BERENSMEIER. 2014. Impact of Nanoparticle Aggregation on Protein Recovery through A pentadentate Chelate Ligand on Magnetic Carriers. Applied Materials and Interfaces 6: 13607-13616.

GAUTAM, A.K., S. SHARMA, S. AVASTHI, R. BHADAURIA. 2011. Diversity, Pathogenicity and Toxicology of $A$. niger: An Important Spoilage Fungi. Research Journal of Microbiology 6: 270-280.

GHOSE, T.K. 1987. Measurement of Cellulase Activities. Pure and Applied Chemistry 59: 257-268.

HART, T.D., D.E. LEIJ FAAM, G. KINSEY, J. KELLEY, J.M. LYNCH. 2002. Strategies for The Isolation of Cellulolytic Fungi for Composting of Wheat Straw. World Journal of Microbiology and Biotechnology 18(5): 471-480.

IMMANUEL, G., C. BHAGAVATH, R.P. IYAPPA. 2007. Production and Partial Purification of Cellulase by Aspergillus niger and A. fumigatus Fermented in Coir Waste and Sawdust. International Journal of Microbiology 3: 147-152.

ISAAC, G.S., M.A. ABU-TAHON. 2015. Enhanced Alkaline Cellulases Production by the Thermohalophilic Aspergillus terreus AUMC 10138 Mutated by Physical and Chemical Mutagens Using Corn Stover as Substrate. Brazilian Journal of Microbiology 46: 1269-1277.

KALYANI, P.C., P.M. ASHWINI, W.C. MOHINI, C.J. SANGITA. 2015. Labscale Production and Purification of Cellulase enzyme from Aspergillus niger. Research Journal of Recent Sciences 4: 124126.

KEERTI, I., A. GUPTA, V. KUMAR, A. DUBEY, A.K. VERMA. 2014. Kinetic Characterization and Effect of Immobilized Thermostable $\beta$-glucosidase in Alginate Gel Beads on Sugarcane Juice. ISRN Biochemistry 2014: 1-8.

KHORSHIDI, K.J., H. LENJANNEZHADIAN, M. JAMALAN, M. ZEINALI. 2016. Preparation and Characterization of Nanomagnetic Cross-Linked Cellulase Aggregates for Cellulose Bioconversion. Journal of Chemical Technology and Biotechnology 91: 539-546.
KIM, J., J.W. GRATE, P. WANG. 2006. Nanostructures for Enzyme Stabilization. Chemical Engineering Science 61(3): 1017-1026.

KIRK, O., T.V. BORCHERT, C.C. FUGLSANG. 2002. Industrial Enzyme Applications. Current Opinion in Biotechnology 13(4): 345-351.

KRAJEWSKA, B. 2004. Application of Chitin-and Chitosan-Based Materials for Enzyme Immobiliza tions: a review. Enzyme and Microbial Technology 35: 126-139.

KUMAR, A., S. SINGH, L. NAIN. 2018. Magnetic Nanoparticle Immobilized Cellulase Enzyme for Saccharification of Paddy Straw. International Journal of Current Microbiology and Applied Sciences 7(4): 881-893.

LAING, Z., J.L. SANG, C. CAO, G. WANG. 2006. Preparation of Urease Immobilized onto Glutaraldehyde Cross-Linked Chitosan Bead. Journal of Science and Technology 27: 123-126.

LEE, S.Y., H. CHEN, M.A. HANNA. 2008. Preparation and Characterization of Tapioca Starch Poly(lactic acid) Nanocomposite Foams by Melt Intercalation Based on Clay Type. Industrial Crops and Products 28: 95-106.

LI, L., G. LI, L.C. CAO, G.H. REN, W. KONG, S.D. WANG, G.S. GUO, Y.H. LIU. 2015. Characterization of The Cross-Linked Enzyme Aggregates of A Novel B-Galactosidase, A Potential Catalyst for The Synthesis of Galacto Oligosa-ccharides. Journal of Agricultural and Food Chemistry 63: 894-901.

LI, S.K., X.C. HOU, F.Z. HUANG, C.H. LI, W.J. KANG, A.J. XIE, Y.H. SHEN. 2013. Simple and Efficient Synthesis of Copper (II)-Modified Uniform Magnetic $\mathrm{Fe}_{3} \mathrm{O}_{4} \quad \mathrm{SiO}_{2}$ Core/Shell Microspheres for Immobilization Of cellulase. Journal of Nanoparticle Research 15: 1-12.

LOWRY, O.H., N.J. ROSEBROUGH, A.L. FARR, R.J. RANDALL. 1951. Protein Measurement with The Folin Phenol Reagent. Journal of Biological Chemistry 193: 265-275.

MANDELS, M., R. ANDREOTTI, C. ROCHE. 1976. Measurement of Saccharifying Cellulase. Biotechnology and Bioengineering Symposium 6: 21-33.

MARTINEK, K., V.V. MOZHAEV. 1985. Immobilization of Enzymes: an Approach to Fundamental Studies in Biochemistry, John Wiley and Sons, Inc., pp: 179-249.

MAT RADZI, S., M. BASRI, A.B. SALLEH, A. ARIFF, R. MOHAMMAD, M.B. ABDUL RAHMAN, RAJA ABDUL R.N.Z., RAHMAN. 2005. High Performance Enzymatic Synthesis of Oleyl Oleate using Immobilised Lipase from Candida antartica. Electronic Journal of Biotechno-logy 8: 291-298.

PADMAVATHI, T., V. NANDYM, P. AGARWAL. 2012. Optimization of The Medium for The Production of Cellulases by Aspergillus terreus and Mucor plumbeus. European Journal of Experimental Biology 2: 1161-1170.

PERIYASAMY, K., L. SANTHALEMBI, G. MORTHA, M. AUROUSSEAU, S. SUBRAMANIAN. 2016. Carrier-free Coimmobilization of xylanase, cellulase and $\beta-1,3-$ 
Glucanase as Combined Cross-Linked enzyme Aggregates (combi-CLEAs) for One-Pot Saccharification of Sugarcane Bagasse. RSC Advances 6: 32849-32857.

PITT, J.I. 1979. The Genus Penicillium and its Teleomorphic States Eupenicillium and Talaromyces. Academic Press, London, pp. 634.

PODREPŠEK, G.H., M. PRIMOŽIĆ, Ž. KNEZ, M. HABULIN. 2012. Immobilization of Cellulase for Industrial Production. Chem. Eng. Trans. (ISBN 97888-95608-18-1) Guest editors: Bardone E, Brucato A, Keshavarz T. 27: 235-240.

PRASANNA, H.N., G. RAMANJANEYULU, B.R. REDDY. 2016. Optimization of Cellulase Production by Penicillium sp.3 Biotech 6: 1-11.

QUIROGA, E., C.O. ILLANES, N.A. OCHOA, S. BARBERIS. 2011. Performance Improvement of Araujiain, A Cystein Phytoprotease, by Immobilization within Calcium Alginate Beads. Process Biochemistry 46: 1029-1034.

RAHIM, S.N., A. SULAIMAN, F. HAMZAH, K.H.K. HAMID, M.N.M. RODHI, M. MUSA, N.A. EDAMA. 2013. Enzymes Encapsulation within Calcium Alginate-Clay Beads: Characterization and Application for Cassava Slurry Saccharification. Procedia Engineering 68: 411-417.

SHELDON, R.A. 2007. Cross-Linked Enzyme Aggregates $\left(\right.$ CLEA $\left.^{\circledR} \mathrm{s}\right)$ : Stable and Recyclable Biocatalysts. Biochemical Society Transactions 35: 1583-1587.

SHERIEF, A.A., A.B. EL-TANASH, N. ATIA. 2010. Cellulase Production by Aspergillus fumigatus Grown on Mixed Substrate of Rice Straw and Wheat Bran. Research Journal of Microbiology 5: 199-211.

SINGHANIA, R.R., A.K. PATEL, C.R. SOCCOL, A. PANDEY. 2009. Recent Advances in Solid-State Fermentation. Biochemical Engineering Journal 44: 13-18.

SOMERVILLE, C. 2006. Cellulose Synthesis in Higher plants. Annual Review of Cell and Developmental Biology 22: 53-78.

SULAIMAN, N.J., R.A. RAHMAN, N. NGADI. 2014. Precipitation of Cellulase and Xylanase for CrossLinked Enzyme Aggregates. Jurnal Teknologi (Sciences \& Engineering) 68: 17-20.

ŠULEK, F., D.P. FERNÁNDEZ, Ž. KNEZ, M. HABULIN, R.A. SHELDON. 2011. Immobilization of Horseradish Peroxidase as Cross-Linked Enzyme Aggregates (CLEAs). Process Biochemistry 46: 765769.

TANG, W.W., G.M. ZENG, J.L. GONG, J. LIANG, P. XU, C. ZHANG, B.B. HUANG. 2014. Impact of

Humic/Fulvic Acid on The Removal of Heavy Metals from Aqueous Solutions using Nano-materials: A
Review. Science of the Total Environment 468: 1014-1027.

VALLET-REGI, M., A. RAMILA, R.P. DEL REAL, J. PÉREZ-PARIENTE. 2001. A New Property of MCM-41: Drug Delivery System. Chemistry of Materials 13(2): 308-311.

VIET, T.Q., N.P. MINH, D.T.A. DAO. 2013. Immobilization of Cellulase Enzyme in Calcium Alginate Gel and Its Immobilized Stability. American Journal of Research Communication 1: 254-267.

WON, K., S. KIM, P. KIM, W. KWANG-JE, HONG S.J. MOON. 2005. Optimization of Lipase Entrapment in Ca-alginate Gel Beads. Process Biochemistry 40: 2149-2154.

XU, J., J. SUN, Y. WANG, J. SHENG, F. WANG, M. SUN. 2014. Application of Iron Magnetic Nanoparticles in Protein Immobilization. Molecules 19: 11465-11486.

XU, J., X. LIU, J. HE, L. HU, B. DAI, B. WU. 2015. Enzymatic in Situ Saccharification of Rice Straw in Aqueous-Ionic Liquid Media using Encapsulated Trichoderma aureoviride cellulase. Journal of Chemical Technology and Biotechnology 90: 57-63.

YE, P., Z.K. XU, J. WU, C. INNOCENT, P. SETA. 2006. Nanofibrous Poly (acrylonitrile-co-maleic acid) Membranes Functionalized with Gelatin and Chitosan for Lipase Immobilization. Biomaterials 27: 4169-4176.

YIN, H., Z.L. SU, H. SHAO, J. CAI, X. WANG, H. YIN. 2013. Immobilization of Cellulase on Modified Mesoporous Silica Shows Improved Thermal Stability and Reusability. African Journal of. Microbiology Research 7: 3248-3253.

YU, H.W., H. CHEN, X. WANG, Y.Y. YANG, C.B. CHING. 2006. Cross-linked Enzyme Aggregates (CLEAs) with Controlled Particles: Application to Candida rugosa Lipase. Journal of Molecular Catalysis B: Enzymatic 43: 124-127.

YU, Y., J. YUAN, Q. WANG, X. FAN, P. WANG. 2012. Covalent Immobilization of Cellulases onto A Water-Soluble-Insoluble Reversible Polymer. Applied Biochemistry and Biotechnology 166: 14331441.

ZAHOOR, S., M.M. JAVED, S. AFTAB, F. LATIF. 2011. Metabolic Engineering and Thermodynamic Characterization of An Extracellular B-Glucosidase Produced by Aspergillus niger. African Journal of Biotechnology 10: 8107-8116.

ZHANG, D., H.E. HEGAB, Y. LVOV, L.D. SNOW, J. PALMER. 2016. Immobilization of Cellulase on A Silica Gel Substrate Modified using a 3-APTES SelfAssembled Monolayer. Springer Plus 5: 1-20. 
Abdel-Sater et al.

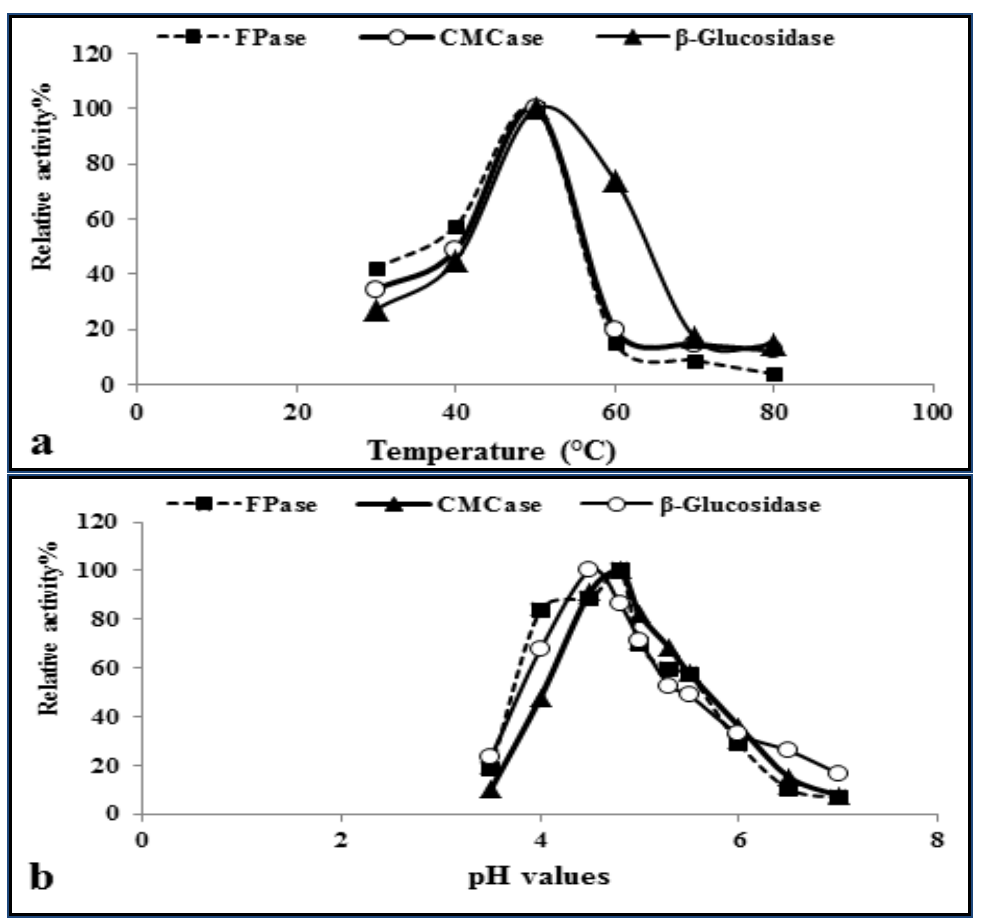

Supplementary (S1): Relative activities of precipitated cellulases (FPase, CMCase and $\beta$-glucosidase) produced by $P$. brevicompactum at different temperature degrees (a) and $\mathrm{pH}$ values (b).

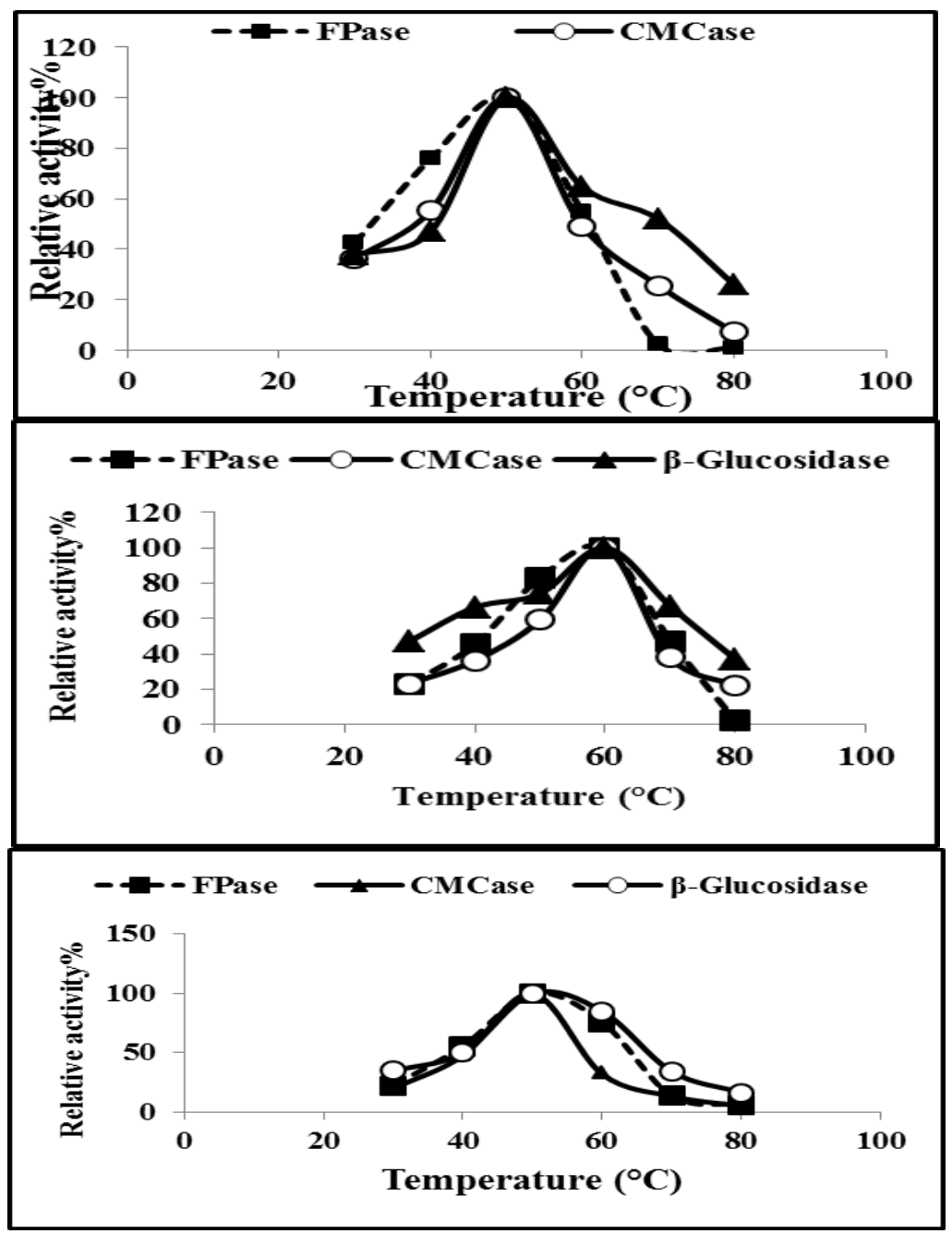

Supplementary (S2): Relative activities of cellulases (FPase, CMCase and $\beta$-glucosidase) immobilized by cross-linking (a), magnetic nannocarrier (b), and $\mathrm{Ca}$ alginate encapsulation (c) at different temperature degrees. 

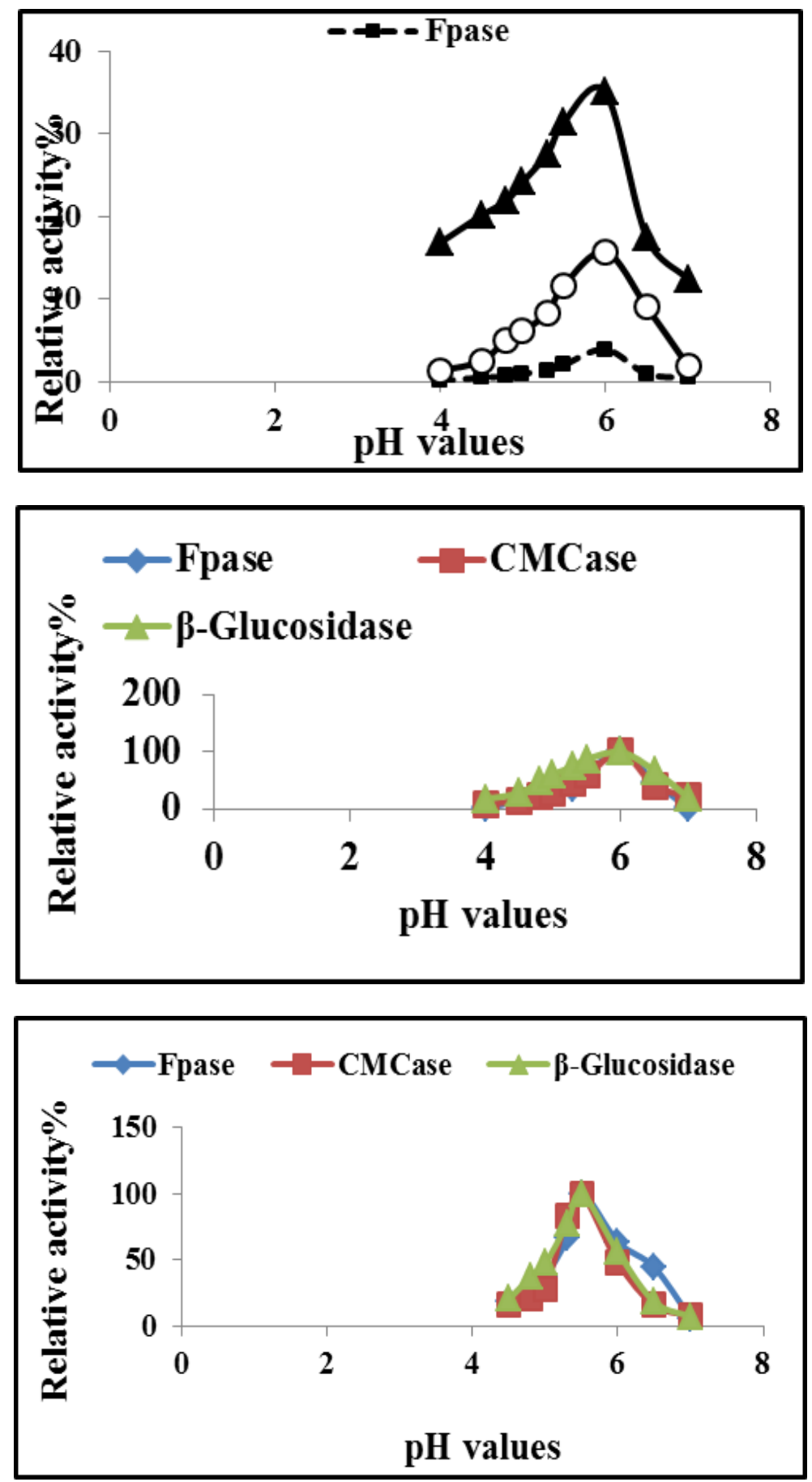

Supplementary (S3)Relative activities of cellulases (FPase, CMCase and $\beta$-glucosidase) immobilized by cross-linking (a), magnetic nannocarrier (b), and Ca-alginate (c) at different $\mathrm{pH}$ values. 


\section{تثبيت انزيمات السلولاز المنتجة بواسطة Penicillium brevicompactum AUMC 10987 ، باستخدام-Cross Encapsulation 9 Chitosan-Coating ‘Linkage}

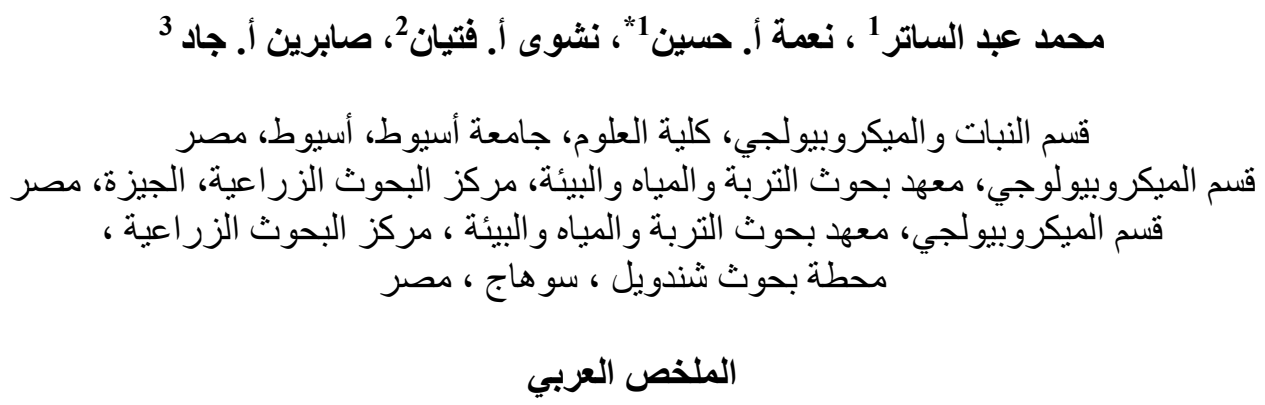

صُمت هذه الدراسة لتحسين الظروف المختلفة وذالك لتحسين إنتاج الإنزيم بواسطة Penicillium brevicompactum AUMC 10987 ، وترسيب وتثبيت انزيمات السلولاز عبر أسلوب الربط المتقاطع باستخدام glutaraldehyde ، و

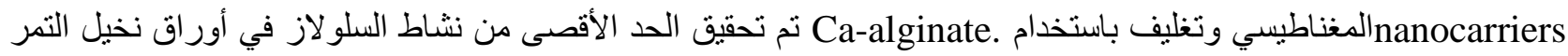
منوسطة الحجم ، نترات الصوديوم ، بعد حضانة تسعه أيام عند 30 درجة مئوية ودرجة الحموضة 6. كان تخمر الحالة الصلبة طريقة أكثر ملاءمة في إنتاج سلو لاز. بعد ترسيب أملاح كبريتات الأمونيوم ، تجاوزت أنشطة الإنزيم مرتين ، مما أدى إلى بناء المزيد من الثبات لهيكل الإنزيم و إعطاء أقصى قدر من الأنشطة عند 50 Co و 4.8 درجة الحموضة. وبالتالي ، يمكن أن يعمل الإنزيم المرسب في ظروف درجة حر ارة وحموضة أعلى. كان عدم الحركة من cellulases بواسطة التغليف التقنية الأكثر قيمة

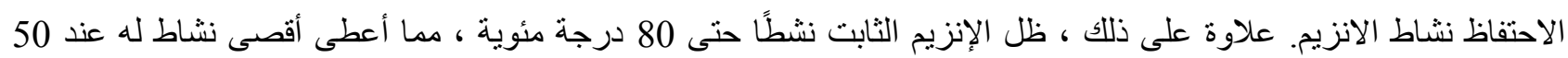
درجة مئوية و 5.5 درجة حموضة. ويفضل أنزيم مغلف داخل حبيبات الجينات بسبب سهولة التركيب ، وظروف الهيلام الخفيفة ،

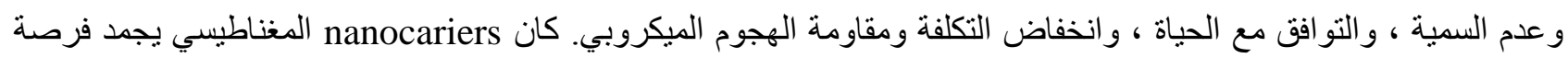
لإعادة استخدامها بعد 4 دورات / 16 ساعة. يمكن أن توفر الدراسة الحالية إنزيم ثابت قوي وقيمة لتطبيقات صناعية وبيوتكنولوجية مختلفة.

كلمات البحث: Cellulase ‘Ca-alginate، Encapsulation ، 